\title{
THE GROWING IMPORTANCE OF THE FINANCIAL SECTOR IN THE FOUNDING COUNTRIES OF THE EUROPEAN UNION
}

\author{
Tomasz Florczak \\ Faculty of Economics and Sociology, University of Lodz \\ ORCID: https://orcid.org/0000-0002-9111-3400
}

\begin{abstract}
The economies of the 21st century countries operate on the principle of connected vessels. A significant element of changes in economies is the growth of the financial sector. The process of financial sector growth is often referred as financialization. The significant impact of this sector on economic development was shown during the financial crisis of 2008. Financialization is more visible in highly developed countries. Undoubtedly the founding countries of the European Union belong to highly developed countries. It is possible that the financialization is higher in bigger countries like France, Germany, Italy or United Kingdom, which can also have bigger financial sectors. From the other side there is also country, which economy is based on banks. The aim of the article is to indicate the growth of the financial sector in the founding countries of the European Union. To determine the growth of the financial sector, the author used the indicators appearing in the literature of subject. There are indicators relating to functioning of the economy and banking sector. The second method helps to determine in which country financialization is higher. To made the research there was used zero unitarization method. The results of the study allows to determine in which of the subjects the financial sector is at a higher level of development. It is possible, that during researched period there were changes in financializiation of researched countries.
\end{abstract}

Keywords: financialization, financial sector, European Union.

JEL Class: G21, G23, G30. 


\section{INTRODUCTION}

The perception of the economy has changed since the middle of the 20th century - particular attention has been paid to the risk and profitability of investments. This was the beginning of economic changes that allowed for increasing the role of the financial sector. In the United States and the global financial crisis as its direct consequence has highlighted the special role of finance. Since then, many activities have been undertaken to study the growth of the financial sector, which is referred as financialization in the literature. Financialization is especially visible in developed and developing countries.

The aim of the article was to compare the growth of the financial sector in the founding countries of th European Union. The research hypothesis was that financialization is higher in countries with bigger economies. In order to verify the research hypothesis, indicator analysis and the zero unitarization method were used.

The first section of the article describes financialization and some of its effects. Next the research methods are described. The results of conducted research for the founding countries of the European Union are presented. The author also undertook a discussion on the results obtained. The last part of the article presents short conclusions resulting from the research.

\section{LITERATURE REVIEW}

After the beginning of financial crisis there began to appear more research on financialization in the literature of the subject. Financialization is the subject of research from various scientific disciplines. Many of the published studies include social changes that illustrate the growing importance of finance in everyday life. In the case of research on the rise of the financial sector there are used various methods - from research containing aggregated economic data to ethnographic research and case studies [Engelen et al. 2014: 1075].

The collapse of the Bretton Woods system was a main event that contribute to the development of the financial sector and financialization. That change led to exchange rate volatility and stimulated changes in accumulation processes. New market situation was taken as the starting point for faster development of financial products. The new market conditions created threats related mainly to floating exchange rates. In response to this threat, several financial instruments were created to hedge market participants. The group of instruments hedging against the risk of floating exchange rates mainly includes futures, options and swaps. The creation of these instruments was the opportunity to create markets for new 
instruments. New markets created opportunities and its side effect became market speculation [Vercelli 2017].

Capital market flows are considered as stimulants of the development of finance. In the literature of subject there were three main flows of private capital [Vasudevan 2009: 291]:

- The first had its beginning in the 1960s and 1970s. It consisted of developing eurodollar markets and increasing sovereign debt. It ended up with a debt crisis of the 1980s.

- The second took place through debt securitization and liberalization on financial markets.

- The third was the inflow of funds to emerging markets, which was the basis for the mechanisms supporting the floating dollar standard.

Financialization is often identified as a derivative of globalization [Bowman 2018: 3-5]. The forces of globalization affect countries differently. It can be observed especially in the effects of the financial crisis of 2008. This theory points to new directions in the study of financialization taking into account the institutional factors of the countries concerned [Alves and Toporowski 2019: 16-20].

Undoubtedly, many events and factors influenced the development of the financial sector. Because of that, it is difficult to find a consistent definition of this process. Therefore, there are many different definitions of financialization in the literature on the subject. Assuming that it includes the basic factors stimulating the development of the financial sector, the following should be considered as financialization [Wiśniewski 2014: 326-329]: increase in the importance of financial transactions in the economy [Turbeville 2014: 5-6], change of type investments from enterprise development into investments aimed at maximizing profits [Batt 2012], increase in the role of financial institutions [Bruno et al. 2013: 1], privatization, destabilization and deregulation of financial markets [Kalogerakos 2013: 22-24].

Various approaches to defining financialization are presented below.

The first of these definitions focuses on the general understanding of financialization. According to this definition, there is a growing separation of the financial sector from the real economy. Bryan pointed unreality related to finance, which has risen too quickly - the indicators determining the finance are growing exponentially, disproportionately to production [Bryan et al. 2009: 459].

Palley argues that the financialization contributes to changes in economic systems and states politics. In addition, it shapes economic results. The main effect of financialization is the increase in the importance of the financial sector in relation to the real part of the economy, the transfer of funds from the real to the financial sector and the increase in wage inequalities and stagnation [Palley 2007: 3-6]. 
In turn, Iain Hardie believes that financialization can be described as the ability to trade risk. In this case, it is understood as both risk taking and risk trading related to the results from the assets. According to this definition, securities markets allow to buy and sell of various types of risk. There are differences between markets due to their liquidity [Hardie 2011: 143]. Hardie distinguishes two basic types of markets:

- Single financial product market (with relatively low financialization) - most outstanding securities are owned by banks and pension funds. The securities remain the property of the said entities until they are repaid.

- A market with a variety of financial products (highly financialized) - these markets are dominated by short-term investors focused on trade. The purchase and sale of numerous financial products is very frequent.

The financialization process develops in various forms. They are often distinguished due to the economic conditions of the area. There are three models for the development of financialization proposed by Till van Treeck [2007: 2-9]:

- increase of profits from non-commercial operations,

- return to highly profitable investments and an increase in cash flows,

- income distribution - an increase in the share of profits in state revenues.

Financialization brings many benefits to economic development. On the other hand, there are also many opinions that after exceeding a certain point it poses a threat to the economy, and its negative effects outweigh the positive ones. According to Imad Moosa, financialization has a negative impact on many aspects of economic life. Among them stands out [Moosa 2018: 3407]:

- capital accumulation,

- consumption,

- productivity,

- employment,

- wages,

- financial stability,

- financial sector complexity.

Changes related to financialization are related with the dynamics of distribution of funds in the economy, including: reduction the share of wages, falling fixed assets investments and shifts in the composition of aggregate demand [Thompson 2013: 474-475]. The decrease of wages is associated with various forms of profit redistribution. Changes in distribution between gross profit and wages have a significant role. This is due to the growing importance of investors focusing on high returns. Therefore, the importance of remuneration is reduced. Another effect of the new ways of distribution of capital the reduction of price competition on the real goods market. This has an impact on the increasing number of mergers and acquisitions. Subsequently, human capital can lose on 
value. The consequence of this situation could be an increase in unemployment [Hein 2009: 14-15].

The effects of the 2008 financial crisis have highlighted the special role of the financial sector in the economies of the 21 st century, for enterprises operating in the economy and for individual fundraising [Jäger and Springer 2015: 5-6]. There is no doubt that there was the change in the attitude of non-financial enterprises to operations in the financial sector, which in particular includes the repurchase of shares, payment of interest, payment of dividends [Crotty 2003: 271-273]. In connection with the above, the increase in financial resources in the economy in recent years has not been accompanied by a corresponding increase in actual accumulation [Glyn 2006].

\section{RESEARCH METHODOLOGY}

Financialization is a process that significantly affects the economies of the 21 st century. The impact of financial sector growth is particularly evident in developed countries. For this reason, the investigated countries are the founder countries of the European Union. The data employed for the study were extracted from the Eurostat database and Financial Development and Structure Dataset published by the World Bank. The years from 2000 to 2017 was adopted as the study period. This choice is caused by the presentation of financial changes before, during and after the financial crisis of 2008.

The research hypothesis was that the degree of financialization is higher in countries with bigger economies. In literature of subject, the most common method of assessing the degree of financialization is the ratio analysis. Mentioned analysis let the author attempt to verify the hypothesis. The study used four indicators relating to the financial system and the banking sector, which include the following indicators:

- the share of public debt to the level of GDP,

- the share of the financial sector in domestic GDP,

- the share of loans to the private sector to GDP,

- the share of the assets of the three largest banks in the total assets of the banking sector.

The results obtained from the abovementioned indicators allowed to approximate which country has a higher value of individual indicators and a higher degree of financialization. In order to obtain a clear result taking into account all applied indicators, the zero unitarization method was used [Balcerzak 2015: 194]. Since all the indicators listed were stimulants of the financialization process, the indicators were normalized in accordance with the following formula [Zygmunt 2017: 511]: 


$$
z_{i j t}=\frac{x_{i j t}-\min _{i t} x_{i j t}}{\max _{i t} x_{i j t}-\min _{i t} x_{i j t}}, \max _{i t} x_{i j t} \neq \min _{i t} x_{i j t}
$$

where:

$z_{i j t} \in[0 ; 1] ; i=1, \ldots, r ; j=1, \ldots, n ; t=1, \ldots, 1$;

$x_{i j t}-$ value of the $i$-th parameter for the $j$-th subject in the $t$-th year, $i=1, \ldots, 5$;

$j=1,2 ; t=1, \ldots, 15$;

$\min _{i t} x_{i j t}$ - minimum value of the $i$-th parameter;

$\max _{i t} x_{i j t}-$ maximum value of the $i$-th parameter.

To obtain one assessment characterizing the examined process, all normalized variables for this entity should be added together.

$$
q_{i j t}=\sum_{\mathrm{i}=1}^{\mathrm{n}} z_{i j t} \quad(i=1, \ldots, r)
$$

In addition, a synthetic $Q_{i}$ variable characterizing the subject has been introduced:

$$
Q_{i t}=\frac{1}{n} \sum_{j=1}^{n} q_{i j t} \quad(i=1, \ldots, r)
$$

Variable $Q_{i t}$ takes values from of range $[0 ; 1]$.

To obtain one assessment characterizing the examined process, all normalized variables for this entity should be added together.

The method used allows for standardization of indicators, which describe the process of financialization by entering their values to the range $[0 ; 1]$. This allows determining the degree of financialization in the entities under consideration taking into account all the indicators examined. The application of the zero unitarization method deepens the indicator analysis used in the literature. The study should be supplemented with the strength of the impact of individual factors on the designated indicator describing financialization.

\section{RESULTS}

The results of the indicator analysis of the process of financialization in the founding countries of the EU are presented in Charts 1-4. Every chart shows the development of indicator values in the 2000-2017 research period. The first of the indicators examined is the ratio of public debt to GDP. This variable is 
a stimulant to financialization. It is because the increase in public debt reveals increased demand for credit money at the state level. Public debt also includes costs of its servicing, which increase the demand for work in the financial sector.

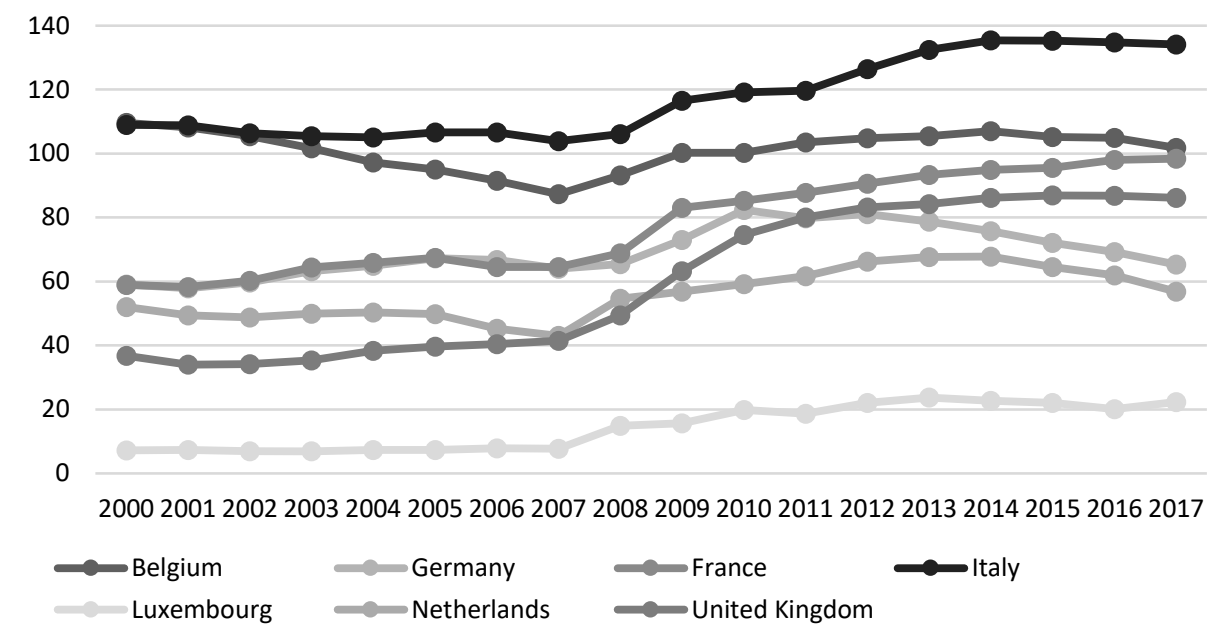

Chart 1. The ratio of public debt to GDP in the founding countries of the European Union in period 2000-2017 (values in \%)

Source: own calculations based on Eurostat Database [access 7.05.2018].

Chart 1 presents the ratio of public debt to GDP in the founding coutries of the EU. During the researched period the value of the indicator increased steadily in majority of researched countries. In Italy and in Belgium there were decreases in the value of indicator. The situation changed after 2007. It is possible, that the financial crisis affected the situation. In majority of cases, there was an increase in public debt relative to GDP after 2007, just like in mentioned countries. This was probably due to the financial crisis on the real estate market.

The second indicator is the ratio of financial sector assets to GDP, which shows the changes in value of banking sector. It is one of the more important ratios to describe financialization. The bigger value of the indicator, the bigger financialization is. The data for researched period are presented on Chart 2 below.

According to the data shown in Chart 2, financial sector assets as the share of GDP level in United Kingdom were the highest in countries under research up to the financial crisis. The value of the indicator was increasing in almost every researched country. The growth stopped in 2009. From that point the value of financial sector assets in GDP were decreasing. The indicator was decreasing whole period in two countries: Belgium and Germany. 


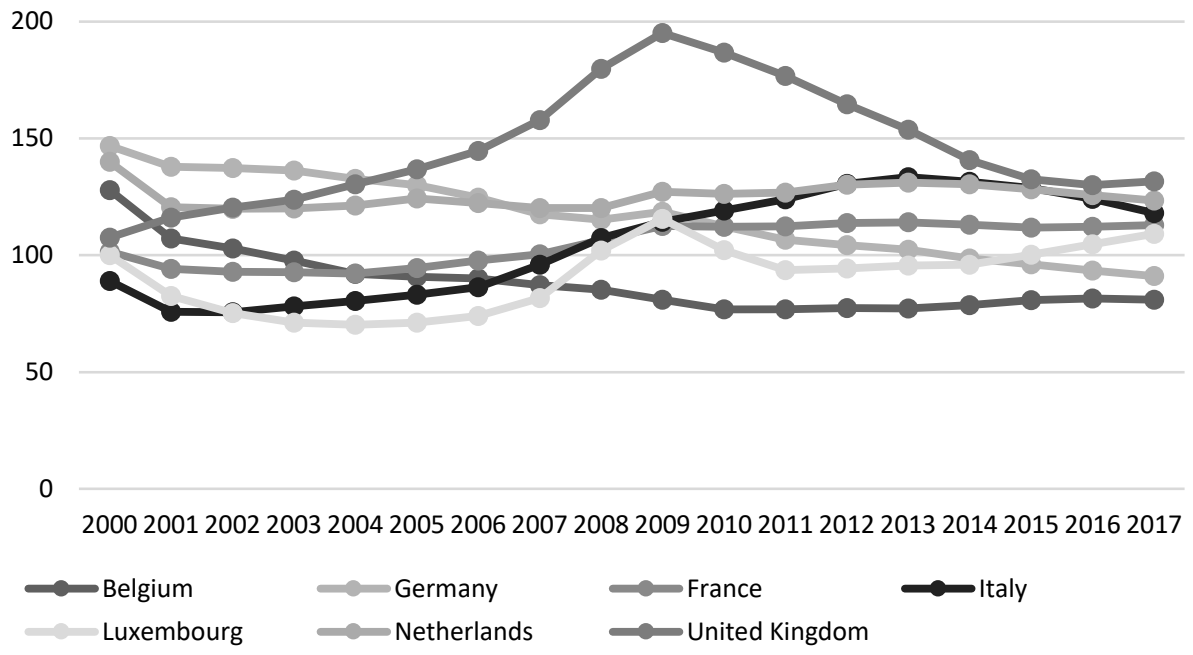

Chart 2. The ratio of financial sector assets to GDP in the founding countries of the European Union in period 2000-2017

Source: Bankscope; World Bank Financial Development and Structure Dataset 2019.

Third indicator is the ratio of loans to the private sector to GDP, which shows the changed of demand for private credit. The ratio is the stimulant of financialization. The data for researched countries are presented on Chart 3.

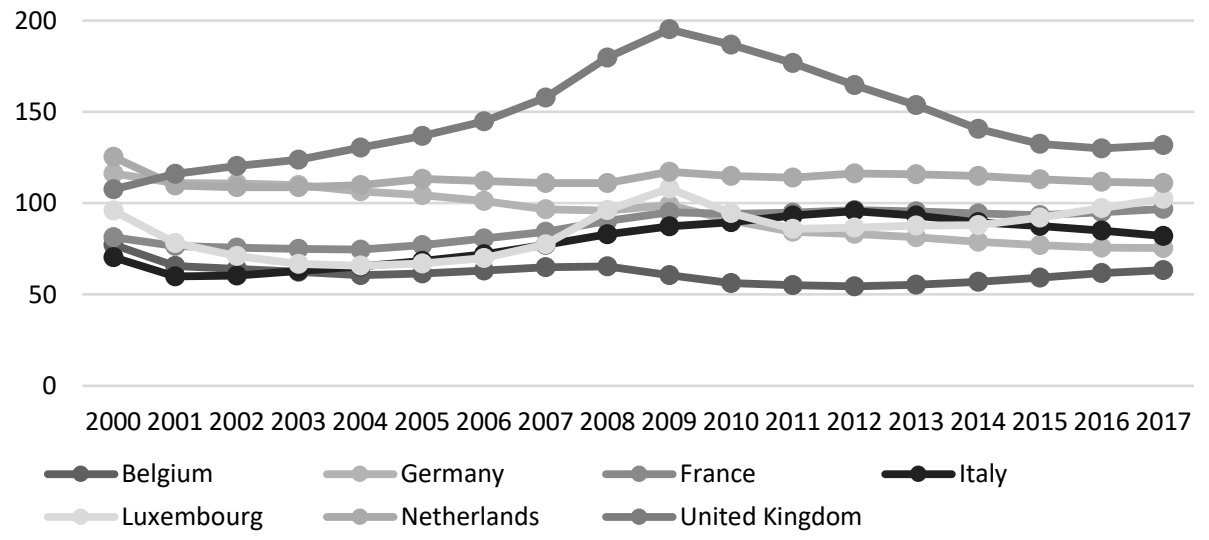

Chart 3. The ratio of loans to the private sector to GDP in the founding countries of the European Union in period 2000-2017 (values in \%)

Source: Bankscope; World Bank Financial Development and Structure Dataset 2019. 
The Chart 3 shows the share of financial sector assets in founding countries of European Union. The presented data show, that the value of the indicator fluctuated in researched period. Germany are the only country, in which the amount of loans to private sector was decreasing for most of researched period. The biggest changes are visible for United Kingdom and Luxembourg. In these two countries the banking sector is one of the most important economy sector. In UK and Luxembourg there was growing up of indicator to 2009. In 2009 the value of indicator started to decrease. In 2011 for Luxembourg and in 2016 for UK the indicator bottomed out to start slightly increase. Probably in mentioned countries the level of financialization is one of the biggest in researched group.

Next chart shows the indicator, which describe the banking sector. The share of three biggest banks assets to banking sector assets shows the bank concentration. It shows the role of biggest banks in banking sectors of researched countries. The data for bank concentration are presented below (Chart 4.).

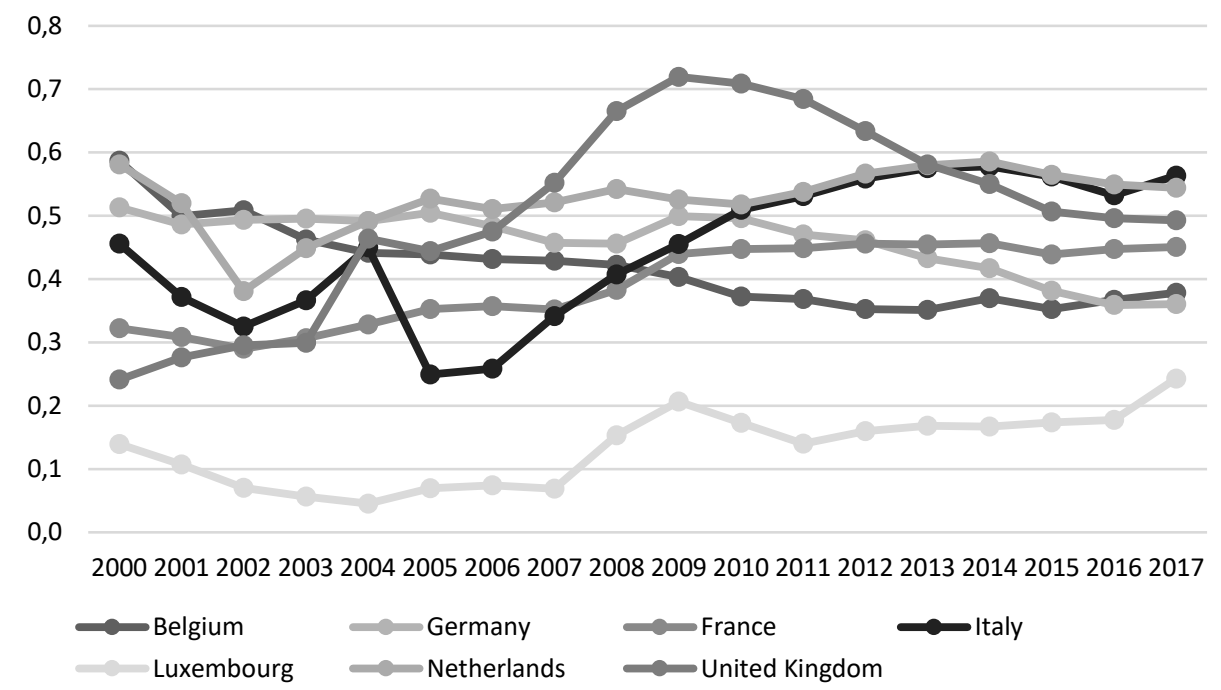

Chart 4. The ratio of the assets of the three largest banks to the total assets of the banking sector in the founding countries of the European Union in period 2000-2017 (values in \%)

Source: Bankscope; World Bank Financial Development and Structure Dataset 2019.

The shape of the Chart 4 demonstrates that the share of the assets of the three largest banks to the total assets of the banking sector fluctuated in researched period. In Italy, there were the biggest changes in the value of indicator. In that country the value of indicator plummed in 2005. The smallest changes were characteristic for France, Luxembourg and Germany. The shape of graph show 
that the bank concentration is not a stable indicator, but it shows the changes in financialization of researched countries.

Next Chart 5 shows the results of dynamic research made by the zero unitarization method. The data are the standardised mean values of all researched indicators.

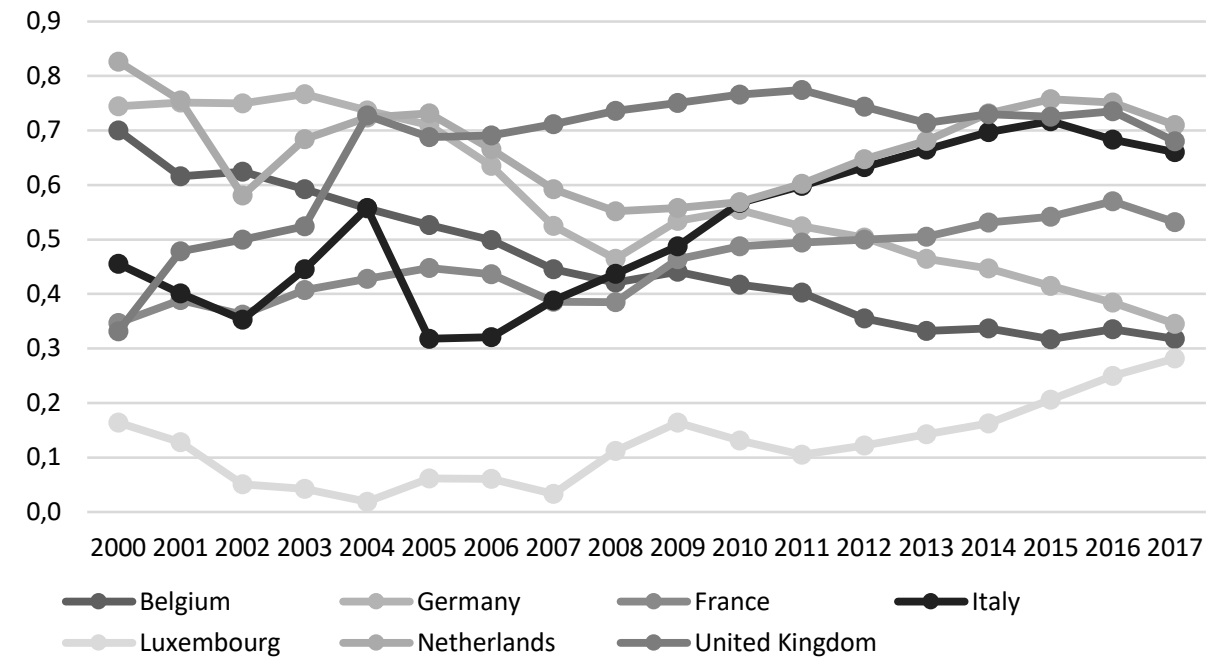

Chart 5. Average value of standardized financialization indicators in the founding countries of the European Union in period 2000-2017

Source: own calculations based on Eurostat Database [access 7.05.2018], Bankscope; World Bank Financial Development and Structure Dataset 2019.

Chart 5 shows the results of the zero unitarization method. It is possible to standardize the values of indicators in the range from 0 to 1 with used method. Sum up the values of the studied quantities may suggest the degree of financialization in researched countries. The period 2000-2017 were used for the study to show the changes in financialization. The choice of period is dictated by the availability of the values of all examined indicators.

The most important moments in researched period are the beginning of period (2000), the beginning of financial crisis (2007-2009) and the last years of researched period (2015-2017).

In 2000 the biggest financialization was in Belgium $(0,587)$ and in Netherlands $(0,581)$. Next countries were Germany $(0,513)$ and Italy $(0,456)$. The smallest financialization was in Luxembourg $(0,139)$, which is described as the country with financial sector as the most important part of the economy. 
The years of the beginning of financial crisis show that the biggest financialization was in United Kingdom, which seems to be the true. That country was probably one of the most impacted by crisis. Next countries with big financialization were Netherlands, Germany and Italy. After period 2007-2009 there came changes in financialization. The first was still UK, but the third was Italy. The end of research period shows the situation after the financial crisis, when majority of its effects have been leveled. In 2017 the country with the biggest level of financialization was Italy $(0,563)$. The UK $(0,493)$ was on the third place. It is visible, that the effects of financial crisis led to change in UKs' financial sector. There are two facts worth to mention in whole period. First one, the Luxembourg had the smallest financialization. Second one, the Germany were steadily decreasing the financialization. The only moment of increase came with financial crisis.

\section{DISCUSSION}

The study indicates the variability of the degree of financialization in the founding countries of European Union. The financial crisis on the real estate market of 2008 may have had a significant impact on the results obtained. The results show, that the level of financialization changes in time. Especially, it is visible in countries under research.

The study described indicates only the impact of four indicators on the development of financialization. The implementation of the zero unitarization method was used by T. Florczak for groups of European Union countries [Florczak 2019]. The zero unitarization method is an alternative to use of the ranks assigned to the values of the indicators for the examined entities. An interesting example of the application of ranks for the examination of financialization indicators for the economies of Central and Eastern European countries was presented by G. Gołębiowski and P. Szczepankowski [2015]. The mentioned article describes both the place of the financial sector in relation to other sectors of the economy and indicators regarding the financial sector. There are the indicators, which describes the role of capital market in economy. The research from this paper can be developed by adding new indicators shown in article about financialization in Central and Eastern European countries. The selection of normalization method could be changed. Every method has its limitations and it's possible, that the use of other method can provide new results. Some of these methods describes K. Kukuła [2000]. 


\section{CONCLUSIONS}

The research made with use of the zero unitarization method indicates changes in the level of financialization in surveyed entities. At the begining of the research period (2000), the financial sector was the biggest in Netherlands. In turn, the analysis the whole period show that the degree of financialization fluctuated and in 2017 the highest level of financialization had Italy. This means that the Italy had better conditions for the development of the financial sector. On the other hand, this sector may be more exposed to a possible crisis. That probability is visible for United Kingdom. UK had the highest level of financialization during majority of researched period to become the second at the end of 2017.

The author accomplished the goal by performing indicator analysis and standardization of variables by the zero unitarization method. Obtained results show the volatility of the situation in the financial sector. The four indicators used to describe the financial sector do not describe all elements related to financialization. Therefore, the analysis should be extended to include more measures describing financial sector.

The zero unitarization method is one of the standardization methods. It is worth to mention that the results obtained with the help of various research methods describing the degree of financialization can be different. It is likely that the results obtained using other standardization methods may show smaller differences in the development of the financial sector in the founding countries of the European Union.

\section{BIBLIOGRAPHY}

Alves C., Toporowski J., 2019, Growth of international finance and emerging economies: Elements for an alternative approach, „PSL Quarterly Review”, vol. 72, no. 288.

Balcerzak, A. P., 2015, Europe 2020 strategy and structural diversity between old and new member states. Application of zero unitarization method for dynamic analysis in the years 2004-2013, „Economics \& Sociology”, vol. 8(2).

Batt R., 2012, The Impact of Financialization on Management and Employment Outcomes, Cornell University, New York.

Bowman A., 2018, Financialization and the extractive industries: The case of South African platinum mining, „Competition and Change”, vol. 22, no. 4.

Bruno V.G.. Büyükşahin B., Robe M.A., 2013, The Financialization of Food?, „Bank of Canada, Working Paper/Document de travail 2013-39”, Ottawa.

Bryan D., Martin R., Rafferty M., 2009, Financialization and Marx: Giving Labor and Capital a Financial Makeover, „Review of Radical Political Economics”, vol. 41, no. 4.

Crotty J., 2003, The Neoliberal Paradox: The Impact of Destructive Product Market Competition and Impatient Finance on Nonfinancial Corporation Performance in the Neoliberal Era, „Review of Radical Political Economics”, vol. 35, no. 3.

Engelen E., Fernandez R., Hendrikse R., 2014, How Finance Penetrates its Other: A Cautionary Tale on the Financialization of Dutch University, „Antipode”, vol. 46, no. 4. 
Eurostat Database, https://ec.europa.eu/eurostat/data/database [dostęp 7.05.2018].

Florczak T., 2019, The process of financialization in groups of European Union member states, [in:] 46th International Scientific Conference on Economic and Social Development - „S Sustainable Tourist Destinations", Book of Proceedings, Varazdin.

Glyn A., 2006, Capitalism Unleashed: Finance, Globalization, and Welfare, Oxford University Press, Oxford.

Gołębiowski G., Szczepankowski P., 2015, Finansyzacja gospodarki krajów Europy ŚrodkowoWschodniej, „Ruch Prawniczy, Ekonomiczny i Socjologiczny”, LXXVII - issue 4.

Hardie I., 2011, How much can governments borrow? Financialization and emerging markets government borrowing capacity, „Review of Iternational Political Economy”, vol. 18.

Jäger J., Springer E., 2015, Debating the future of Europe. Critical political economy and post-Keynesian perspectives, [in:] Asymmetric crisis in Europe and possible futures. Critical political economy and post-Keynesian perspectives, Routledge Tayleor \& Francis Group, London.

Hein E., 2009, A (Post-)Keynesian perspective on 'financialization', „IMK Studies”, vol. 1.

Kalogerakos T., 2013, Financialization, the Great Recession, and the rate of profit: Profitability trends in the US corporate business sector, 1946-2011, „Lund University - School of Economics and Management", Lund.

Kukuła K., 2000, Metoda unitaryzacji zerowanej (Zero unitarization method), PWN Scientific Publishing House, Warsaw.

Moosa I.A., 2018, Does financialization retard growth? Time series and cross-sectional evidence, „Applied Economics”, vol. 50, no. 31.

Palley, T., 2007, Financialization: What It Is and Why It Matters, „Annandaleon-Hudson, NY: The Levy Economics Institute Working Paper", no. 525.

Thompson P., 2013, Financialization and the workplace: Extending and applying the disconnected capitalism thesis, „Work, Employment and Society”, vol. 27, no. 3.

Turbeville W., 2014, Financialization and a New Paradigm for Financial Markets, Demos/New Economic Paradigms/Rockefeller Foundation.

Wiśniewski P., 2014, Nowe miary finansjalizacji, [in:] Rozwój nauki o finansach. Stan obecny i pożadane kierunki jej ewolucji, SGH Warsaw School of Economics, Warsaw.

World Bank Financial Development and Structure Dataset 2019, https://www.worldbank.org/en/ publication/gfdr/data/financial-structure-database [dostęp 10.03.2020].

Van Treeck T., 2007, A Synthetic, Stock-Flow Consistent Macroeconomic Model of Financialisation, „Macroeconomic Policy Institute (IMK) in the Hans Boeckler Foudation Working Paper", no. 6.

Vasudevan R., 2009, Dollar Hegemony, Financialization, and the Credit Crisis, „Review of Radical Political Economics", vol. 41, no. 3.

Vercelli A., 2017, Crisis and sustainability. The Delusion of Free Markets, Macmillan Publishers Ltd., London.

Zygmunt A., 2017, Innovation activities of Polish firms. Multivariate analysis of the moderate innovator countries., „Oeconomia Copernicana”, vol. 8(4). 